Journal of Finance and Banking Review

Journal homepage: www.gatrenterprise.com/GATRJournals/index.html

J. Fin. Bank. Review 2 (1) $17-24$ (2017)

\title{
Profit and Loss Sharing System - Solution for Trade-offs between Banking Profitability and Economic Efficiency of Intermediation
}

\author{
Asfi Manzilati* \\ Faculty of Economic and Business, Brawijaya University, Jl. MT. Haryono 165, 65145, Malang Indonesia
}

\begin{abstract}
Objective - The higher the difference between the loan interest and the deposit interest is, the better it is for a bank. This reflects a higher margin/profitability. However, it also shows less efficiency of the intermediation mechanism. Using literature research, this study aims to understand how the mechanism of Profit and Loss Sharing System (Islamic Banking System) can become the solution for the trade-off.

Methodology/Technique - This study uses literature search and review as the method to gain an understanding of the fundamental concept as well as to offer critique by noting the trade-offs associated with the micro and macro objectives of banking.

Findings - In the profit and loss sharing system made accessible through partnership, the returns that will be earned by one part depends on the other part. This requires each part to behave professionally and responsibly. Depositors' returns depend on banks' returns and banks' returns depend on mudharib's return. Therefore, there is no difference between banking profitability and efficiency of the intermediation.

Novelty - With the same implications noted between the micro objective of banks (advantage as a business entity) and the efficiency of intermediation as well as the implications for the affordability and social justice, there is no trade-off between profitability and economic efficiency of intermediation. In addition, the profit and loss sharing system can also be a solution for the trade-off itself.
\end{abstract}

Type of Paper: Review

Keywords: Profit and Loss Sharing System, Micro-macro Trade-off, Banking Profitability, and the Economic Efficiency of Intermediation.

JEL Classification: G21, G32.

\section{Introduction}

A bank is an entity that compromises a big part of the economy. Banks mobilize, allocate and invest the greatest part of the economic agents' savings. Accordingly, their performance has substantial consequences on capital allocation, firm expansion, industrial growth and economic development. Therefore, efficiency and profitability of banks is of interest, not just at the individual bank level, but also at a broader macroeconomic level (Iloska, 2014).

\footnotetext{
* Paper Info: Received: January 17, 2017

Accepted: March 14, 2017

* Corresponding author:

E-mail: asfi@ub.ac.id; asfi6886@gmail.com

Affiliation: Faculty of Economic and Business, Brawijaya University, Indonesia
} 
Every bank, like any other business and economic system (conventional or Islamic), has a common goal to make profit. It takes a lot of efforts to achieve these gains, a lot of efforts must be done. Many research deals in detail with how banks seek to make profits and their performances. I these studies, a variety of macro variables were noted and considered. Meanwhile, discussions that connect banks' profits as institutions (entity) with implications for macroeconomic are relatively limited. One discussion in this regard was written by King and Levine (1993) who connected financial intermediation and economic development. Another discussion was about financial inclusion by the World Bank (2014).

Looking at the lack of studies, this paper thus aims to discuss the relationship between the individual goal of banks (i.e. profit) with implications for the efficiency of intermediation, especially against affordability (accessibility) and social justice. This paper also aims to note the differences existing in the system of conventional banks with their profit-and-loss sharing systems (Islamic system).

\section{Research Method}

This study uses the literature review method to collect data. The method was chosen with the view of understanding the fundamental concepts noted in the system of conventional banks with their profit-and-loss sharing systems (Islamic system) as well as to critique the concepts where trade-offs are associated with the micro and macro objectives of banking. As explained by Skene (n.d), the study of literature has to survey all the relevant literature so as to determine what is known and not known about a particular topic. The literature review method, as suggested by Parahoo (2006), is a systematic review that should detail the time frame within which the literature was selected as well as the methods used to evaluate and synthesize findings of the studies in question. In order for the reader to assess the reliability and validity of the review, the following precise criteria used are presented:

To formulate the research question:

- Set inclusion or exclusion criteria

- Select and access the literature

- Assess the quality of the literature included in the review

- Analyse, synthesize and disseminate the findings.

In contrast to quantitative research which comprises of a deductive method of analysis in obtaining results, this study uses a qualitative research approach by synthesizing its inductive method gained from the quantitative so as to answer the research objectives. For the purpose of the literature review, a meta-synthesis is applied. Meta-synthesis is the non-statistical technique used to integrate, evaluate and interpret the findings of multiple qualitative research studies. Such studies may be combined so as to identify their common core elements and themes. Findings from the phenomenological, grounded theory or ethnographic studies may also be integrated and used. Unlike meta-analysis, where the ultimate intention is to reduce findings, meta- synthesis involves analyzing and synthesizing key elements in each study, with the aim of transforming individual findings into new conceptualizations and interpretations (Polit \& Beck, 2006).

\section{Banking Profitability}

Like most companies in general, the bank's profit is derived from the total revenue minus its total expenditure. In a financial institution, the profits are derived from financial services. In conventional banks, interest is the main income of the bank. In looking at the banks of this system, the advantage is known as the spread which is the difference between the interest earned on loans and advances and the interests paid on deposits and borrowings by the banks (Godse, 1984).

The in-depth discussion of banking profitability is approached by a discussion of the bank's performance. This is done by considering the internal and external factors (Erina, 2013). Internal indicators are bank size, 
operating efficiency, capital, credit risk, portfolio composition and asset management (Ramlall, 2009). These rates are variable and controllable. External indicators include the macro-economic changes which banks are unable to exert control over since their impact occurs on the macro-level. Two main macroeconomic indicators that were used to determine the bank's earning capacity are: 1) growth of annual gross domestic product (GDP) and 2) annual inflation (INF). Gross domestic product growth (GDP) shows the total economic activity is determined by demand and supply of bank loans and deposits as well as the financial services industry's profitability (Bikker \& Hu, 2002).

However, internal and external factors are the basis for the calculation or consideration in the interest rate determination and policy. In turn, the bank's profit remains to focus on the difference between the mortgages interest on deposits. The greater the difference between the two, the greater the advantage received by the bank (the owner).

That is, the bank profits achieved by widen the spread through internal factors, namely operating efficiency, capital, credit risk, portfolio composition and asset management by taking into account external factors. Meanwhile, profits in a bank which uses a profit and loss sharing system are obtained by different mechanisms. The interest rate serves as the only source of fund that traditional banks are receiving whereas in Islamic Banks "profit/loss sharing" methodology is used. The banking principles, rules, regulations and equity structure are different for both types of banks (Faizulayev, 2011). In the case of Islamic banks, there is a flexibility of becoming shareholders and creditors of firms as well as the advantage of providing investment-banking services (Bashir, 2003).

Sharing is the key word on how Islamic Banks operate and make a profit. In the operating mechanism, the relationship between the bank and its customers (both depositors and investors/mudharib) is a partnership relationship. This means that the parties will share the results among themselves. These results are either profit/ returns or loss/risks. The higher the returns obtained by mudharib, the greater the results obtained by the bank, and in turn, the greater the profit/return sharing received by depositors. The advantage enjoyed by the owner (bank) will be linear with the profits and/or results obtained by customers (both mudharib and depositors).

\section{Economic Efficiency of Intermediation}

The importance of bank markets (as well as financial markets, in general) can be seen as evolving from the traditional view which was proposed by King and Levine (1993). This traditional view of financial intermediaries assume that organizations passively funnel household savings to business investments. The "New view of financial intermediation" however, has a much richer vision of the nature and the economic function of these organizations. Indeed, financial intermediaries are viewed as playing an active, perhaps even dominant roles in the organization of the banking industry.

Thus far, the main focus of a bank's role (financial institutions in general) is to measure (only) the value of the bank's performance in the industry and its economic growth. The efficiency of the role it performs, the extent to which the bank as the owner of the funds (depositor) shares "profits" with the public or the user of the funds (investor) or how the bank becomes the largest rent taker against both has not been much discussed.

The theory that was used to study financial intermediation was developed first of all in the 60's and it started with the works of Gurley and Shaw. The financial intermediation theory is based on the theory of informational asymmetry and the agency theory. In principle, the existence of financial intermediaries is explained by the existence of the following categories of factors: high cost of transaction, lack of complete information in useful time; and the method of regulation (Andries, 2009).

At the level of the bank as a business entity, the transaction cost approach could be used as a method for measuring the efficiency of the intermediation. Transaction costs approach that measures the efficiency of bank intermediation can be done either from the demand side or the supply side. On the demand side, transaction costs can be calculated by identifying the variables suspected to affect the cost-effectiveness of customer transactions (Supranoto, 2002). From the supply side, the cost of banking transactions can be calculated by tracing the additional costs that arise as the forming (deciding) factor of the price of credit. One method of 
determining the price of bank credit used is cost-plus loan pricing (Rose \& Hudgins, 2005; Kasmir, 2004), the pricing of credit is based on the basic costs, fixed costs and variable costs.

Transaction costs reflect the institutional design created by the banking institutions. The larger the transaction costs, the more inefficient the institutional design made by a banking institution. In relation to the major activity that the banking sector performs as intermediary institutions, it is noted that inefficiency and ineffectiveness of banking institutions can certainly disrupt the intermediation function. Only banks that operate effectively and efficiently are able to perform the intermediation function properly (Listiyanto \& Manzilati, 2007).

The implication of the low efficiency of intermediation is the low level of access and social justice. If people have to pay large prices or expenses for obtaining bank services then gaining access/affordability of the bank's service for the communities will be low. Similarly, if the cost (both in the form of "price", procedures, and other requirements) to obtain the bank service is high, the people served by banks would decrease. In turn, social justice will be lower.

\section{Interest and Trade-Off between Banking Profitability and Economic Efficiency of Intermediation}

According to the model of perfect financial markets in the neo-classical theory, the following conditions are fulfilled: no one participant can influence the prices; the placement/borrowing conditions are identical for all participants; there are no discriminatory fees; there is a lack of competitive advantages at the level of participants; all financial securities are homogeneous, dividable and transactional; there are no transaction costs for obtaining information or of insolvency; all participants have immediate access to complete information regarding the factors and elements that can influence the current or future value of the financial instruments (Andries, 2009).

In a perfect financial market, the interest not only serves as the price but also as a "controlling factor" of the balance of the fund market (Loanable funds market). Based on the characteristics of a perfect market, the price will be close (or almost equal) to the cost of production thus, the manufacturer can only obtain normal profits (especially in the long term). Analogous to the above description, the interest (the sale price of funds) will approach the deposit rate (the purchase price of the fund). The small difference between the mortgage interest on deposits (known as spread), the intermediation role of banking institutions (and other financial institutions) are thus, more efficient.

However, it is still based on the assumption of neoclassical theory (the other) that a rational economic actor will certainly try to gain as much as possible. This is then followed by the owners of the bank who will seek to maximize profits. To achieve these objectives, the high spreads is the main source of profit. Coupled with imperfect financial markets, then the spread will be directed to get higher in order to cover the risk premium. In summary, banking as a business entity will maximize profitability through higher spreads.

Banks' efforts to maximize profits through spreads is common over rationality (neoclassical). However, the purpose of micro (profit) is not necessarily in line with the macro implications as an intermediary institution. In the interest of a banking system, it turns out that there are trade-offs between the goals of the bank as a business entity (profit) with the bank as an intermediary institution. Advantages of the banking system with interest (roughly) is the difference between the mortgage interest on deposits (called the spread). The bigger the spread the better because it means the bank's profit increases. At the same time, greater spreads (plus a risk premium) means the cost of intermediation paid by public is also getting heavier.

On the other hand, the interest system brings the consequence that any transaction between the bank and its customers (both savers and borrowers) will be based on the contract debts (debt base). It would also bring different consequences and even contradictory to the micro (profitability) and macro (economic efficiency of intermediation) level. On the micro level, the difference in lending interest to deposit interest is the bank's profits (called the spread). The higher the spread, the greater the profit for the owner. While on the macro level, spread indicates low cost of funds (in the form of interest on deposits) and high selling price of funds (in the 
form of credit interest). This means that savers get smaller reward and/or expensive cost of credit. In other words, the costs of the public (in the form of affordability) on intermediation role becomes low.

The interest system also brings other consequences namely increasing fixed costs both component costs of banks and component costs charges on credit recipients. Fixed (and predetermined) costs plus debt based, in turn, become a risk to injustice. This is because the good or bad conditions for one party will not change the gain (fixed) received by the other party. Moreover, if the cost (both in the form of "price", procedures, and other requirements) to obtain the bank service becomes higher, the people who are served by the banks decreases (read: it is a rich society). In turn, it lowers the social justice.

\section{Profit and Loss Sharing; the Solution of the Trade-Off between Banking Profitability and Economic Efficiency of Intermediation}

"Financing must be for a worthwhile cause." In conventional banking, "worthwhile" means profitable. This is not so in Islamic banking (Khan \& Mohammed, 2010). The following questions were derived from the above:

How does Islamic bank achieve its purpose as business entities as well as intermediary institutions?

Can a profit and loss sharing system negate as well as become a solution to the trade-off of the micro-macro?

The profit and loss sharing system is based on a transaction contract of equity based investments. The relationship between the customer (depositor or mudharib) with the bank is a partnership relationship. Partnership relations will have implications on how the return and risk are divided. With this relationship, the bank's profit depends on the profit of mudharib in accordance to the agreed profit sharing ratio and the return obtained by depositors depend on the results obtained by bank.

Similarly, on the implications of the risk, partnerships also has risk-sharing consequences. When mudharib (investor) suffers a loss or at the least, do not make a profit, then the bank in this position as the owner of the funds (shahibul mal) must also bear the risk of capital loss. In turn, the decline in bank business conditions will impact the results obtained by the depositors. The linearity of the results obtained by each party has consequences on the achievement of the profit goals of the bank.

How does the profit and loss sharing system impact the efficiency of intermediation? Again, this system makes linear returns and risks of the parties. This linearity makes the parties share the results, either positive results in the form of profits or negative results in the form of risk/loss. Linearity and the sharing system will make each of the parties work hard and act efficiently. In turn, the overall (macro objectives) will be efficient.

Equity is also related to consequences on the affordability and fairness. It can be seen from the arguments the relationship between the bank's operating system and the company's costs. The implications of the difference system (interest and profit and loss sharing) to company's costs appears on the curve as follows: 


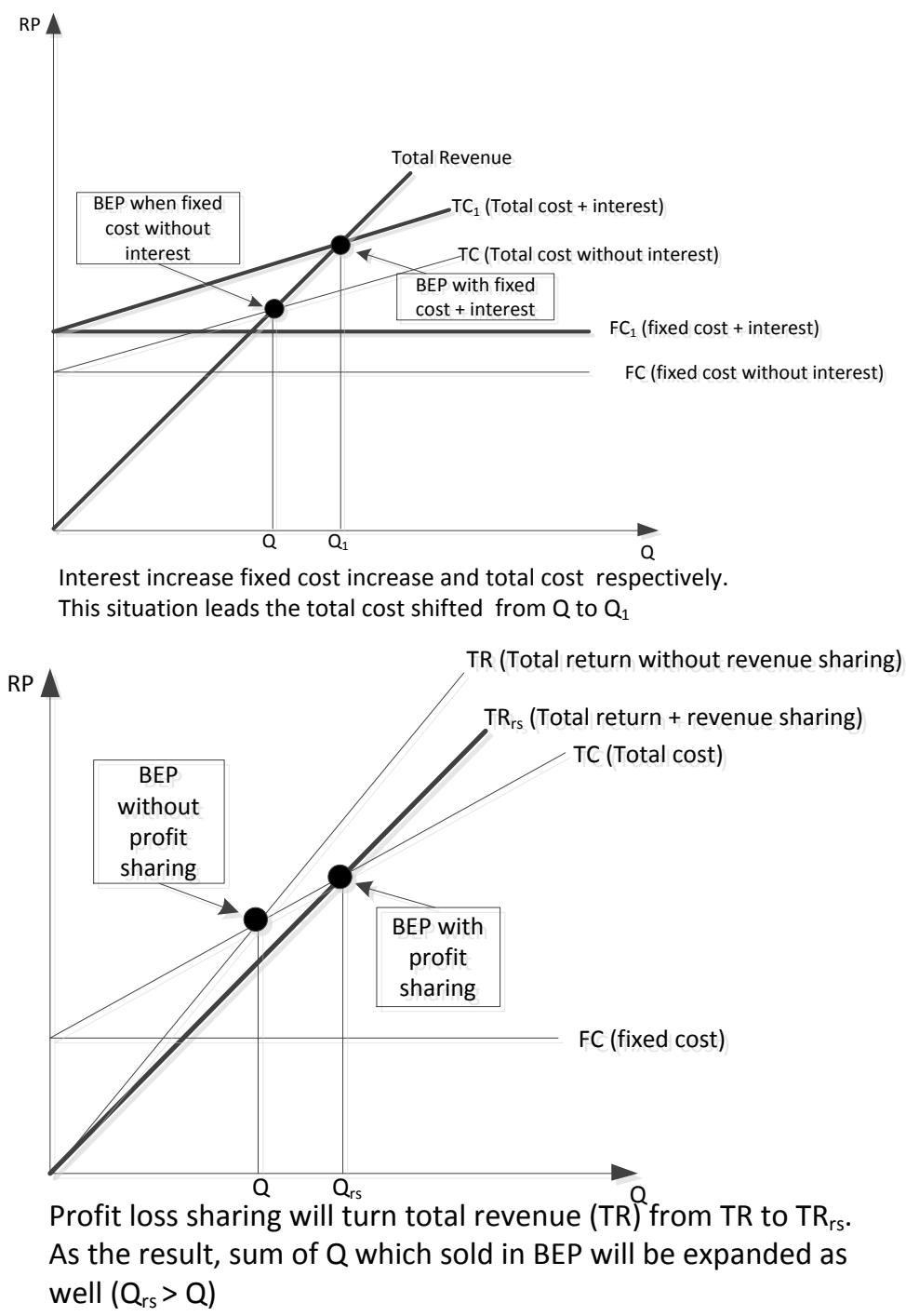

Figure 1. Interest and profit and loss sharing Source: Karim, 2008

With this system, mudharib is unencumbered by fixed costs (like the system interest). With returns based on the outcomes obtained, the results are thus variable, turning it into affordable financing (in accordance with the business conditions). However, if the conditions are stagnant, the result system can then avoid capital erosion due to fixed costs (like the system interest).

The profit and loss sharing system will also bring in better social justice. There are a few reasons. First, the linearity of the results enables the parties to enjoy the result and/or bear the risk together. This system thus avoids the situation where one party wins and the other loses. Second, the contract and percentage of revenue sharing is done based on mutual agreement. According to the term "worthwhile" in Islamic banking, the banker must do the best and be trusted (amanah). Investment return contains the obligation for the banker to set aside a part of the profit as zakat. In fact, one of the most important tools for Muslims to ensure wealth redistribution and transfer from rich to poor is zakat (Badawi, 1979). This implies that any increase in the income of the parties concerned (savers, banks and mudharib) will improve the distribution of wealth to the community

With the same implications noted between the micro objective of the bank (advantage as a business entity) and intermediation efficiency followed by the implications for affordability and social justice, there is thus, no trade-off, between profitability with the economic efficiency of intermediation. 


\section{Conclusion}

From this paper and the findings observed, a few deductions are arrived. First in looking at the interest system, it can be said that the higher the spread, the greater the profits are for the owners. In looking at the macro level, it can be said that spread indicates low cost of funds (in the form of interest on deposits) and high selling price of funds (in the form of credit interest). This means that savers get smaller rewards and/or expensive costs of credit. In other words, the costs incurred by the public (in the form of affordability) on the role of intermediation becomes low.

Further, in the profit and loss sharing system, through partnership, the returns that will be earned by one part depends on the other. This arrangement leads to a greater professionalism and higher responsibility within each part. The depositor's return, clearly, depends on the bank's return and the bank's return depends on the mudharib's return. Therefore, there is no difference between banking profitability and the efficiency of intermediation.

With the same implications noted between the micro objectives of banks (advantage as a business entity) and the efficiency of intermediation followed by the implications for the affordability and social justice, there is no trade-off between profitability with the economic efficiency of intermediation. In addition, the profit and loss sharing system can also be a solution for the trade-off itself.

\section{References}

Andries, A. M. (2009). Theories regarding financial intermediation and financial intermediaries-a survey. The Annals of the" Stefan cel Mare" University of Suceava. Fascicle of The Faculty of Economics and Public Administration, 9(2 (10)), 254-261.

Badawi, I. A. A. A. Q., Zaki, M. A., \& ul Amwal, K. (1979). Zakat and Social Justice. Islamic Council of Europe, London..

Bashir, A. H. M. (2003). Determinants of profitability in Islamic banks: Some evidence from the Middle East. Islamic economic studies, 11(1), 31-57.

Bikker, J. A., \& Hu, H. (2012). Cyclical patterns in profits, provisioning and lending of banks and procyclicality of the new Basel capital requirements. PSL Quarterly Review, 55(221).

Erina, J., \& Lace, N. (2013). Commercial banks profitability indicators: empirical evidence from Latvia. IBIMA Business Review, 2013, 1, Article ID 873515, DOI: 10.5171/2013.873515

Faizulayev, A. (2011). Comparative analysis between Islamic banking and conventional banking firms in terms of profitability, 2006-2009 (Doctoral dissertation, Eastern Mediterranean University (EMU)).

Godse, V. T. (1984). Productivity in Banks-Concept and Measurements. Bank Economists Meet, 298.

Iloska, N. (2014). An Analysis of Bank Profitability in Macedonia. Journal of applied economics and business, 2(1), 3150 .

Karim, A. A. (2008). Ekonomi Makro Islami, Edisi 3, Jakarta.

Kasmir. (2004). Pemasaran Bank. Edisi 1. Prenada Media. Jakarta

Khan, B., \& Mohammed, E. A. C. (2009). The Value of Islamic Banking in the current financial crisis. Rev. Banking \& Fin. L., 29, 441.

King, R. G., \& Levine, R. (1993). Financial intermediation and economic development. Capital markets and financial intermediation, 156-189.

Listiyanto, E., \& Manzilati, A. (2007). Analisis Biaya Transaksi Pada Industri Bank Umum Di Indonesia. Journal of Indonesian Applied Economics, 1(1).

Parahoo, K. (2014). Nursing research: principles, process and issues. Palgrave Macmillan.

Polit, D. F., \& Beck, C. T. (2006). Essentials of Nursing Reserarch: Methods, appraisal, and utilization. (6th ed). Lippincott Williams and Wilkins, Philadelphia

Ramlall, I. (2009). Bank-specific, industry-specific and macroeconomic determinants of profitability in Taiwanese banking system: under panel data estimation. International Research Journal of Finance and Economics, 34(2), 1450-2887.

Rose, P. S., \& Hudgins, S. C. (2005). Bank management \& financial services. McGraw-Hill. 
Skene, A. (n.d) Writting a litereture review. The Writing Centre, University of Toronto at Scarborough. (http://www.utsc.utoronto.ca/ ctl/twc/terms.htm). Accessed in August, 2016.

Supranoto, M. (2002). Biaya Transaksi Nasabah Bank Perkreditan Rakyat. Jurnal Keuangan dan Perbankan Perbanas. 4, (1), 25-50

World Bank, (2014). International Bank for Reconstruction and Development, Washington DC 